\title{
Transferring differentiation \& integration through picking up students' speech by Hip-hop and its appreciation
}

\section{KEYWORDS}

HHBE in IB; HHPED in IB; differentiation through Hip-hop; integration through Hip-hop; IB transfer skills through Hip-hop

\begin{abstract}
Janiec Jerzy, Transferring differentiation and integration through picking up students' speech by hip-hop and its appreciation. Culture - Society - Education no 2(16) 2019, Poznań 2019, pp. 23-44, Adam Mickiewicz University Press. ISSN 2300-0422. DOI 10.14746/kse.2019.16.2.

The main aim of this paper is to demonstrate the Hip-hop based Education (HHBE) and Hip-hop Pedagogy (HHPED) as two accommodating strategies that may be utilized fourishingly to differentiate a teaching-learning process further to integrate learners in any education-like environment, as the example the IB World School No. 006654 International School of Bydgoszcz (ISOB) has been chosen. This is the first study presenting international community in a truly homogeneous society (ca. 98\% of Polish inhabitants in their country). The author enlists affirmative methodologies beginning with a hypothesis that the Hip-hop culture is gaining popularity among adolescents in greater numbers. As a result of observations, interviews and survey he is acquainted with students' wants and needs. There is a necessity to put them in a bigger picture by analyzing the phenomenon from a historical, sociological, political, economical and intercultural viewpoint on a local (Bydgoszcz's) and global scale. And finally, the author is describing a use of the aforesaid strategies through transfer skills that are taught in the IB History and Social Studies classes.
\end{abstract}

* ORCID: https://orcid.org/0000-0002-9874-6286. 


\section{The source of inspiration}

The main aim of this investigation would be formulated in students' flow that originates from Hip-hop based Education and Pedagogy (abb. HHBE \& HHPED; Banks, 2015; Love, 2014; 2015) and is taken from the author's Stylo Theory "do you have thrills thinking on how Hip-hop industry is collecting bills?/ All ya need is a beat to be labeled as a hit/ lyrics are recognized as long as they are memorized/ we won't discuss tastes, but just a way genre braces/ producing famous Adidas laces/ that introduce open spaces/ for imagining its stars faces/ becoming unnatural graces" (Janiec, 2018e). In other words, discussion on Hip-hop popularity will be undertaken in order to provide a room for the learners' education on challenges they are facing while growing up these days. Their catalogue starts with self-acceptance through access to a homogeneous society up to understanding truth, honesty, and lie in the International School of Bydgoszcz's (ISOB's) community set in the city of Bydgoszcz, Kuyavian-Pomeranian voivodeship (Poland).

Moreover, practicing mnemonic techniques will be examined as a form of the International Baccalaureate's (IB) Approaches to Learning (ATL) transfer skills (IB, 2018) in acquiring English as a second language during History and Social Studies classes. To add, operating Critical Pedagogy (Freire, 2005: 43-79; Shor, 1992: 129; Tinson \& McBride, 2013) will be analyzed as a tool for boosting learners to find their identity, hobbies further a direction to express their personal and artistic self.

And lastly, treating all of the above as a self-motivational learners' factor will be advised to proceed at school and perhaps further in life.

The author has already ascertained that inspiration is a revelation defined by a person or group of people, who is installing the insight's source in any form. Its process of growing up and someday transformation might change somebody's perception on a special matter that is momentous while listening to Tinie Tempah's and Eric Turner's "Written in the Stars" ${ }^{1}$ hit. This must be the first documentation of the Stylo theory. More paramount is an ability and keenness to discover any unknown land with assistance of your G10 learners during "Funtime Dance Show"2 event as well as the school's Middle Years Program Personal Project (Belka, 2013: 14-15; Nowacka, 2013: 6-7; Ramirez-Sygutowska, 2013: 8).

Another proof is a fact that the Harvard's University student Obasi Shaw, under an English lecturer Josh Bell's supervision, from Stone Mountain, Georgia

\footnotetext{
1 The song from Tempah's album entitled "Disc-overy" from 2010.

2 Miejski Dom Kultury on Marcinkowskiego Street no. 12-14 in Bydgoszcz organized its second edition on June 8, 2013.
} 
graduated from with honors after submitting a 10-track rap album entitled "Liminal Minds" (Obasi, 2018; Zatat, 2017). He was writing lyrics and beats performing them at "open mic nights" (Zatat, 2017) on the school's grounds and as a result Obasi's mother guided his son on the idea to use his creative expression on the academic level. The Harvard graduate student is rapping on one's African American identity from different views adopting Geoffrey Chaucer's "The Cantenbury Tales" scheme plus James Baldwin's records on slavery and police's brutality (Obasi, 2018; Zatat, 2017).

This what actually has shaped the author's source of inspiration starting the growing up process and possible transformation was information on adding two Hip-hop albums, namely Nas' "Illmatic"3 and Kendrick Lamar's "To Pimp a Butter-

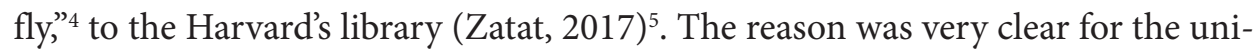
versity's English lecturers, so their impact on a society and culture (Zatat, 2017). As the follow up to the author's inspiration, Lemar has won four Grammy awards for the Best Rap Performance: "HUMBLE.", the Best Rap Album: "DAMN.", the Best Rap/Sung Performance: "LOYALTY." feat. Rihanna and the Best Rap Song: "HUMBLE." plus Pulitzer's prize all in one year, so 2018 (Coscarelli, 2018). On one hand, it put to a test appropriateness of the Harvard's decision by approving it. On the other hand, it substantiates intentions of the Hip-hop representatives, who are still fishing for an African American's storytelling style with a message to the society and modern-like package of music genres used in order to serve everything on a plate.

The most momentous juncture in the Hip-hop culture is freestyle, similarly in dancing and rapping. There is a chance to stumble upon the most far-reaching news plus music, in the suitable style, thanks to the Hot 97 station $^{7}$ since 1992. During one of the broadcasted programs there led by DJ Funkmaster Flex The Roots' (Chang, 2005) legendary front man Black Thought demonstrated all his views in 10 minutes long freestyle (Kreps, 2017). It helped a lot in moving back in the past to "The Foundations" (the first episode of Wheeler's documentary from

3 The album was released on April 19, 1994 by Colombia Records, so a division of Sony Music Entertainment.

${ }^{4}$ The album was released on March 16, 2005 by Aftermath/Interscope (Top Dawg Entertainment).

${ }^{5}$ A Hip-hop producer 9th Wonder has already expanded the library's catalogue on "The Miseducation of Lauryn Hill” plus A Tribe Called Quest's “The Low End Theory”, see: http://library.harvard.edu/lauryn-hill-nas-kendrick-lamar-albums-entered-harvard-library.

${ }_{6}^{6}$ The album was released on April 14, 2017 by Aftermath/Interscope (Top Dawg Entertainment).

7 The official website: http://www.hot97.com. 
2016) of the Hip-hop style with such mythical South Bronx live battles heroes like DJ Kool Herc, Afrika Bambaataa or Grandmaster Flash (Chang, 2005). The author is ought to mention in a chronological order its way from "The Underground to the Mainstream" (after the second episode of Wheeler's documentary, 2016; Chang, 2005) with the Sugarhill Gang and their Top 40 hit. The action has not stopped there keeping in mind "The New Guard" (after the third episode of Wheeler's documentary, 2016) with Run-D.M.C., Def Jam or Rakim. Not forgetting about the one and only Public Enemy (Chang, 2005). "The Birth of Gangsta Rap" (after the fourth episode of Wheeler's documentary, 2016) results in a necessary fact to mention the West Coast deputies of Hip-hip like Ice-T and N.W.A., and more (Chang, 2005). To understand trends and pick up the speech you just must have such a lesson. Working as a historian the author of this investigation is prescribed to dig a little bit deeper acquiring knowledge from different sources of information. His student, who pinpointed that

I have always wanted to learn or go through the history of how Hip-hop dancing began and developed, which I never had the time to pursue, has already reflected his ambition in a similar fashion. I also really wanted to get to know the story behind this style of dance, because in order to be a real dancer, you must know and respect the history as well as being good in doing it (...). (Ramirez-Sygutowska, 2013: 8)

What's also essential, it is required to pinpoint the author's great respect towards uplifting merit and historically-wise phenomenon that is standing behind the aforesaid type of music further style of life that has been cultivated by many African American musicians first, and not only nowadays (Chang, 2005; Hill, 2009; Wheeler, 2016).

\section{The literature's review}

Wonderment for the HHPED and the HHBE has been intensified as a result of their flexible application through academic Howard Gardner's Multiple Intelligence Theory (Banks, 2015). The HHBE's research on a group of urban as well as suburban teachers, who are keen to equip students in knowledge on Hip-hop, is reflecting who, why, where and how educators are constructive in that matter (Irby \& Hall, 2013). In some sort of a continuation of this study the authors are sharing their reflections on "schooling" K-12 teachers (Irby et al., 2013). The ISOB school is fulfilling the elementary education representatives wants and needs, namely Primary Years Programme (PYP) students, organizing an extracurricular classes on dancing Hip-hop. 
Moreover, younger and older students are using $30 \mathrm{~min}$. lunch breaks as a time to dance taking the school's floor thanks to our principal's initiative, she is dee-jaying, that parents also support. In this sense to a higher degree rousing is Bettina L. Love's (2015) article on the Hip-hop culture and its influence on early childhood plus elementary education. In many books and articles urban education system is introduced as environment where a given scholarly ground correlate with the Hip-hop values' utilization with a great emphasis on "becoming" from student's and teacher's outlook (Emdin, 2017). To add, its application might be seen as a natural factor there as a result of youth's attraction to the aforesaid customs and information that the culture is "taking the throne" (Boykins, 2017; Lynch, 2018). On the other hand, there is still a question of international-mindedness to be introduced from hands-on access in the subject matter. Moreover, through what medium it may be attainable for multicultural community, which is living in a homogenous society, to integrate with using the HHBE plus HHPED strategies.

'Rapping,' 'b-boying, 'dee-jaying' and 'graffiti' are elucidated as the four developmental pillars in and within class' setting (Emdin, 2013a). Moreover, Jay-Z (Chang, 2005) said once that rap is poetry and as a result its operation as another educational strategy is astonishing. We only need to take into consideration the Northeastern USA experience on that occasion (Hall, 2016). The HHPED might be adopted in teaching politics and identity (Hill, 2009a), and literature through ethnographic writing (Hill, 2006), plus storytelling (Hill, 2009b).

What's more, cautiousness in dealing with Hip-hop is advised, especially if it comes to Social Studies (Kumar, 2017). Whereas, we do have a positive study from Atlanta, Georgia testing the culture as well as teaching strategies on topics, like society, politics, justice and race, etc. (Love, 2012). To add, another forward-looking example of the Hip-hop values used in Social Studies classes was taken from Chicago, where students were dealing with social injustice (Stovall, 2013). Geoff Harkness (2012) used a rhetorical figure of "authenticity" while deciphering a question of insiders' and outsiders' relationships in Chicago's Hip-hop underground setting. A reader needs to be informed on history of segregation in the city's suburbs in order to perceive its signification (Pulido, 2009; Wood, 2013). That's why studies on a way in which young Black males are treated at schools (Love, 2014a) and urban youth, who fight successfully with stereotypes through storyboarding and moviemaking are so far-reaching (Love, 2014b).

In terms of dealing with strategies of teaching and learning we are up to add the "Folkbildning" from the Scandinavian countries that is making the Hip-hop sophistication recognizable also in the national education system (Söderman, 2011). 
If it comes to Hip-hop pedagogies, the Pedagogy of the Oppressed is a basis for the HHBE that is using socio-politically-wise ambience as a trigger for further proceedings (Freire, 2005; Shor, 1992). A very similar approach we can find in the Critical Pedagogy and Radical Education that both are presenting characteristics of the Radical Teacher (Tinson \& McBride, 2013). The Reality Pedagogy's five backbones that may work as a methodological science teacher's support are as follows (Emdin, 2013b):

a) cogenarative dialogues;

b) co-teaching;

c) cosmopolitanism;

d) context incorporation;

e) content development with its continuation and extension (Emdin et al., 2016). ${ }^{8}$

The Hip-hop's self-aesthetics plus kinetic consumption (Kline, 2007) including justice-oriented culture and the Hip-hop's autonomy and distance aesthetics allow students' identification of positive and negative practices (Petchauer, 2013), similarly working on a self-determination (Love, 2016). We are ought to find content in undeniably valuable aesthetics of the Hip-hop culture (Petchauer, 2015) taking into consideration the Culturally Responsive Pedagogy through its historical context further its future (Petchauer, 2017). In the Historically Black College and University (HBCU), also thanks to "HipHop2020" project, the Hip-Hop Leadership Pedagogy was popularized and recommended (Wilson, 2013). The culture's influence on a higher education and its students was a topic of discussion (Petchauer, 2012) with extension on the professional rappers, who have been offering courses for adolescents (Seidel, 2011).

Joan F. Smutny and S.E. von Fremd (2004: xii-xiv) derive a word curriculum from Latin that means, "to run" asking teachers to treat learning as a journey. They produce five steps in order to be prepared for a long trip. Firstly, teachers are ought to know their children. Secondly, to decide on their destination, then there is a need to provide a proof that the destination was reached. In step four we can plan a journey with a final fifth step is upcoming reassessment plus adjustments (Smutny \& Fremd 2004). This definition of differentiation may open the doors for the HHBE and HHPED. Both have not been demonstrated as a helpful tool in teaching History and Social Studies in English as the second language for a majority of international community yet.

\footnotetext{
${ }^{8}$ Acronym STEM that stands for science, technology, engineering and mathematics with the Hip-hop's socio-emotional guidance provided for learners.
} 
The Hip-hop might be seen as a style of life when we will take into account mnemonics techniques very helpful in programs dealing with dementia that are improving people's lives (Noble et al., 2016). Moreover, we can mention the assessment of a school-based stroke literacy program, entitled the "Hip-hop Stroke", with a strong suggestion to inform school children aged 9 to 12 years on the matter, who may be helpful in sharing knowledge with their parents in a high risk minority communities (Williams et al., 2012a) plus its program evaluation (Williams et al., 2012b). There is a necessity to introduce very beneficial and in the same time productive curriculum with the F.A.S.T. mnemonic acronym that refers to stroke symptoms and desirable reaction: "Facial droop, Arm weakness, Speech disturbance, Time to call 911" (Williams \& Noble, 2008) that actually works very well.

Lastly, Hip-hop may be correlated with calorie label interventionism, thanks to which a food purchase done by children is constantly improving (Williams et al., 2016).

\section{Methods}

\section{Data}

A routine of collecting data on the Hip-hop was inaugurated through all of the convenient media, so computers through internet connection with an access to social media, TVs, newspapers, magazines, journals and radio stations since very late 1990's and at the beginning of the $21^{\text {st }}$ century. The first examinations and following them some conclusions suggested that an extensive amount of adolescents could have been affected by the aforementioned cultivation.

\section{Survey}

A hypothesis bestowed in such manner demanded being double-checked on the ISOB ground thanks to a survey entitled "Hip-hop: Pick up the majority's Speech" (Janiec, 2018f). It was shared among 54 participants in total, what is shown in table 1.

Table 1. The ISOB's Community Participants' detailed Characteristics

\begin{tabular}{|l|l|l|l|l|}
\hline Participant & Group age & Status & IB Program & Nationality \\
\hline 6 & $12-13$ & Grade 6 students & Middle Years & Hungarian, French, Polish \\
\hline 9 & $13-14$ & Grade 7 students & Middle Years & Greek, Spanish, Polish \\
\hline 6 & 15 & Grade 8 students & Middle Years & Greek, Spanish, Dutch, Polish \\
\hline 4 & $15-17$ & Grade 9 students & Middle Years & Indian, Polish \\
\hline
\end{tabular}




\begin{tabular}{|l|l|l|l|l|}
\hline 3 & 17 & Grade 10 students & Middle Years & French, Polish \\
\hline 5 & 18 & Grade 11 students & Diploma & German, Polish \\
\hline $\begin{array}{l}\text { (including } \\
\text { graduates) }\end{array}$ & $18-21$ & Grade 12 students & Diploma & $\begin{array}{l}\text { Greek, Turkish, Italian, Spanish, } \\
\text { Polish }\end{array}$ \\
\hline 14 & $\begin{array}{l}\text { Above 20 } \\
\text { years old }\end{array}$ & Parents & Both & British, Spanish, Polish \\
\hline
\end{tabular}

Source: the author

\section{Observations and interviews}

Moreover, on the basis of experiencing the genre including long-term observations and interviews it was attainable to make this research. Its outcomes prove that in Bydgoszcz students are attending the Hip-hop dance classes in the following local institutions:

a) Adelante. Dance Studio9;

b) Bailamos Dance Studio: Robert Linowski, Carolina Linowska ${ }^{10}$;

c) Dance Academy. Dance Studio. Agata Szybiak-Loukini, Radosław Gołata ${ }^{11}$;

d) Dance Creation Studio. Neumann B. M. ${ }^{12}$;

e) Dance Factory - Dance Studio ${ }^{13}$;

f) Dance School "Bohema"14;

g) Up2Excellence - Dance Studio Bydgoszcz ${ }^{15}$

What's more, the city's Hip-hop scene is still conquering no man's lands socially by introducing new lyrics as well as beats, EPs and full-length albums. It is almost impossible to mention all of the crews including individual artists from the aforesaid place. The listeners emphasize a great admiration towards Bydgoszcz's Azja, Bejot PROD, Bisz, Chio EMB, Daras, Dj Jeżu, Dwie Strony Medalu, ESZ.E, Grande, Haker, KESZ, Merol, Oer (B.O.K.), Olszak, Osa WL, OZI, Pafarazzi, PARTYZANT, Person Sativa Skład, Szula WL, Śpioł, Tata Kres, TEGONIEZNOSISZ, Trach, WMW, WPL Ekipa and Wujas for their artistic achievements.

9 Adelante. Studio tańca. The official website: http://www.u2e.pl.

10 The official website: http://bailamos.pl.

11 Studio Tańca Dance Academy Agata Szybiak-Loukini, Radosław Gołata. The official website: http://taniec-bydgoszcz.pl.

${ }^{12}$ Studio Kreacji Tańca. Nauka tańca. Neumann B. M. The official website: http://studiokreacjitanca.pl.

${ }^{13}$ Fabryka Tańca - Studio Tańca. The official website: http://www.fabrykatanca.com.

${ }^{14}$ Szkoła Tańca "Bohema". The official website: http://www.szkolabohema.pl.

${ }^{15}$ Up2Excellence Studio Tańca Bydgoszcz. The official website: http://www.u2e.pl. 
To add, in the interest of admins, who are running a webpage entitled the city of Bydgoszcz Rap, ${ }^{16}$ is a fact to provide the latest news in our area of interest, for instance Bydgoszcz's Freestyle Battle (BBF), music production workshops for free, the latest albums' listening parties, etc. A few of them one could have matched with bouts literally taken from New York's Hip-hop venues like described by Chang (2005).

\section{HHBE \& PED methodologies}

The information was associated with methodologies that were used, so the HHBE strategy (Banks, 2015: 243) in order to produce rhymes and songs simultaneously by students and teachers in the classroom. The author decided to share his works prepared in the "GarageBand" software for Macintosh devices to produce concept-based curriculum dependent on the historical apparatus. The HHPED strategy (Banks, 2015: 243) was helpful in discussing mainly historical as well as linguistic aspect of the culture in the classroom.

\section{Results}

\section{Survey}

Literally, the survey, prepared via Smart Survey website, was addressed to everybody, who had interest in sharing assumptions on the Hip-hop culture at least to some extent momentous in his or her life. Its differentiation determined by the age is shown in table 2 .

Table 2. Age group analysis

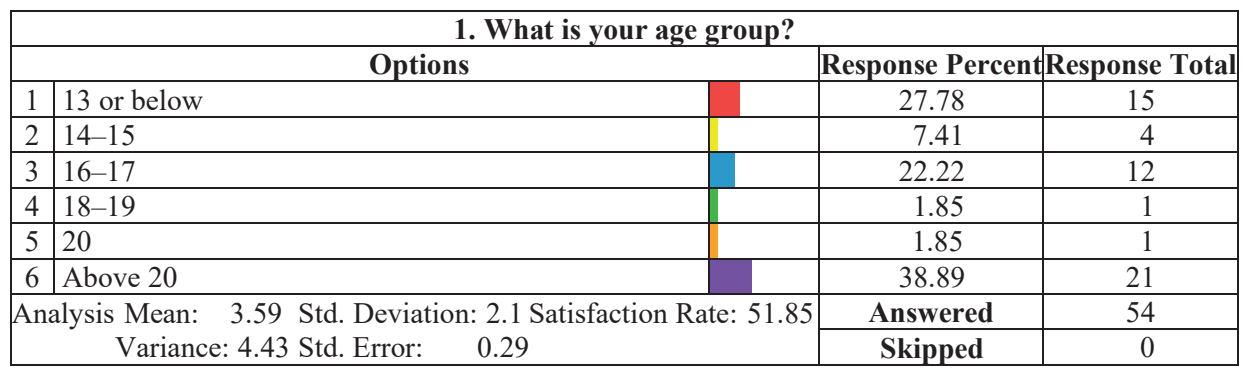

Source: Janiec, $2018 \mathrm{f}$

${ }^{16}$ Bydgoski Rap. The official website: https://bydgoskirap.wordpress.com. 
Deciphering results from the table 3 we are assured by participants that our subject of interest is seen predominantly positively as a dance, rhymes and beats subculture. For some of them, chiefly the ISOB's students, it is a style of life. On the other hand, in order to balance affirmative perspective the same amount of contributors replied that Hip-hop is correlated with "gangsta" or that they have not ever found this subject as something entertaining.

Table 3. Hip-hop culture description

\begin{tabular}{|c|c|c|c|}
\hline \multicolumn{4}{|c|}{ 2. Hip-hop is for me... } \\
\hline \multicolumn{2}{|r|}{ Options } & \multicolumn{2}{|c|}{ Response Percent/Response Total } \\
\hline 1 & Style of life & 29.63 & 16 \\
\hline 2 & Dance / rhymes and beats / subculture & 77.78 & 42 \\
\hline 3 & Unquestionably "gangsta" & 24.07 & 13 \\
\hline 4 & Something I don't like / don't find interesting & 24.07 & 13 \\
\hline \multirow{2}{*}{\multicolumn{2}{|c|}{$\begin{array}{c}\text { Analysis Mean: } 3.54 \text { Std. Deviation:1.97 Satisfaction Rate: } 66.05 \\
\text { Variance:3.87 Std. Error: } \quad 0.27\end{array}$}} & Answered & 54 \\
\hline & & Skipped & 0 \\
\hline
\end{tabular}

Source: Janiec, $2018 \mathrm{f}$

Another two tables correspond with each other. On account of frequency of listening to the Hip-hop music (table 4), there is an emergency to provide appropriate application or media, thanks to which participants will be able to listen to the genre (table 5). We can assume that even in the international community there is extremely large likelihood that youth may be interested in the lifestyle, which is answering on their wants and needs on the grounds of their growing up process as well as a feeling of being outsider in a homogeneous society.

Table 4. Frequency of listening to the Hip-hop music

\begin{tabular}{|c|l|c|c|c|}
\hline \multicolumn{3}{|c|}{ 3. How often do you listen to Hip-hop? } \\
\hline 1 & Options & Response Percent & Response Total \\
\hline 2 & Occasionally & From time to time & 44.44 & 24 \\
\hline 3 & Often & 12.96 & 7 \\
\hline 4 & Every day & 14.81 & 8 \\
\hline
\end{tabular}

Source: Janiec, $2018 \mathrm{f}$

Table 6 is encouraging a reader to emphasise a process of benchmarking certain time span by teenagers, their parents as well as teachers in a form of the Hip-hop so-called benefactors (patrons). Foundations for that are set not only in the options that were picked by the participants, but exclusively on precisely 28 long-lasting plus individual specifications. These blueprints serve as a basis for the author's History and Social Studies HHBE \& HHPED curriculum. 
Table 5. Available platforms to listen to the Hip-hop music

\begin{tabular}{|c|c|c|c|}
\hline \multicolumn{4}{|c|}{ 4. Where do you usually listen to Hip-hop? } \\
\hline \multicolumn{2}{|r|}{ Options } & \multicolumn{2}{|c|}{ Response Percent Response Total } \\
\hline 1 & $\begin{array}{l}\text { Thanks to music services: iTunes, Spotify, Deezer, } \\
\text { etc. }\end{array}$ & 52.83 & 28 \\
\hline 2 & \begin{tabular}{|l|l} 
I have a very rich "library" on my device \\
\end{tabular} & 20.75 & 11 \\
\hline 3 & Radio, TV, etc. & 37.74 & 20 \\
\hline 4 & \begin{tabular}{|l|l|} 
Other & \\
\end{tabular} & 35.85 & 19 \\
\hline \multirow{2}{*}{\multicolumn{2}{|c|}{$\begin{array}{c}\text { Analysis Mean: } 3.51 \text { Std. Deviation: } 2 \text { Satisfaction Rate: } 67.92 \\
\text { Variance: } 3.98 \text { Std. Error: } \quad 0.27\end{array}$}} & Answered & 53 \\
\hline & & Skipped & 1 \\
\hline
\end{tabular}

Source: Janiec, $2018 \mathrm{f}$

Table 6. The Hip-hop eras

\begin{tabular}{|c|c|c|c|c|}
\hline \multicolumn{5}{|c|}{ 5. What is your favourite Hip-Hop era? } \\
\hline \multicolumn{3}{|c|}{ Options } & Response Percent & Response Total \\
\hline \multicolumn{3}{|c|}{ Old School Hip-Hop (1970's up to early 80’s) } & 9.43 & 5 \\
\hline \multicolumn{3}{|c|}{2 The Notorious B.I.G.'s Era } & 1.89 & 1 \\
\hline \multicolumn{3}{|c|}{3 Eminem's Era is in the making } & 18.87 & 10 \\
\hline \multicolumn{3}{|c|}{4 Kendrick Lemar's Era } & 0.00 & 0 \\
\hline 5 & \multicolumn{2}{|c|}{ Jay-Z's Era } & 5.66 & 3 \\
\hline 6 & \multicolumn{2}{|l|}{ Drake's Era } & 7.55 & 4 \\
\hline 7 & \multicolumn{2}{|c|}{ Kanye West is the best } & 3.77 & 2 \\
\hline & \multicolumn{2}{|c|}{ Other (please specify): } & 52.83 & 28 \\
\hline \multirow{2}{*}{\multicolumn{3}{|c|}{$\begin{array}{c}\text { Analysis Mean: } 5.92 \text { Std. Deviation: } 2.56 \text { Satisfaction Rate: } 70.35 \\
\text { Variance: } 6.56 \text { Std. Error: } \quad 0.35\end{array}$}} & Answered & 53 \\
\hline & & & Skipped & 1 \\
\hline \multicolumn{5}{|c|}{ Other (please, specify): (28) } \\
\hline \multicolumn{5}{|c|}{$1 \underline{29 / 01 / 188: 43 P M} \quad$ I listen to many eras } \\
\hline \multicolumn{2}{|r|}{$2 \underline{29 / 01 / 188: 46 \mathrm{PM}}$} & \multicolumn{3}{|c|}{ I listen to many eras } \\
\hline & $\underline{29 / 01 / 189: 04 P M}$ & \multicolumn{3}{|c|}{ Polish Rap/Hip-Hop ( $21^{\text {st }}$ century) } \\
\hline & $\underline{\text { 29/01/18 9:56PM }}$ & \multicolumn{3}{|c|}{ A lot of rappers } \\
\hline & $\underline{29 / 01 / 18 ~ 10: 17 P M}$ & \multicolumn{3}{|c|}{$\begin{array}{l}\text { Wu-Tang Clan and N.W.A. as well as the current era with artist like Kendrick Lemar, } \\
\text { 6lack and G-Eazy }\end{array}$} \\
\hline & $\underline{30 / 01 / 185: 39 A M}$ & \multicolumn{3}{|c|}{ I don't have any } \\
\hline & $\underline{30 / 01 / 186: 58 \mathrm{AM}}$ & \multicolumn{3}{|c|}{ Big Sean } \\
\hline 8 & $\underline{30 / 01 / 186: 05 \mathrm{PM}}$ & \multicolumn{3}{|c|}{ None of the above } \\
\hline 9 & $\underline{30 / 01 / 186: 27 \mathrm{PM}}$ & \multicolumn{3}{|c|}{ I don't know them, but I like how hip-hop as dance look like now. } \\
\hline \multicolumn{5}{|c|}{ 5. What is your favourite Hip-Hop era? } \\
\hline \multicolumn{3}{|r|}{ Options } & Response Percent & Response Total \\
\hline & $\underline{30 / 01 / 186: 49 P M}$ & \multicolumn{3}{|c|}{ Today's era } \\
\hline & $\underline{31 / 01 / 187: 38 \mathrm{AM}}$ & \multicolumn{3}{|c|}{$\mathrm{A} 2 \mathrm{M}$} \\
\hline & $\underline{31 / 01 / 187: 38 \mathrm{AM}}$ & \multicolumn{3}{|c|}{$\mathrm{A} 2 \mathrm{M}$} \\
\hline & $\underline{31 / 01 / 187: 39 \mathrm{AM}}$ & \multicolumn{3}{|c|}{ A2M } \\
\hline
\end{tabular}




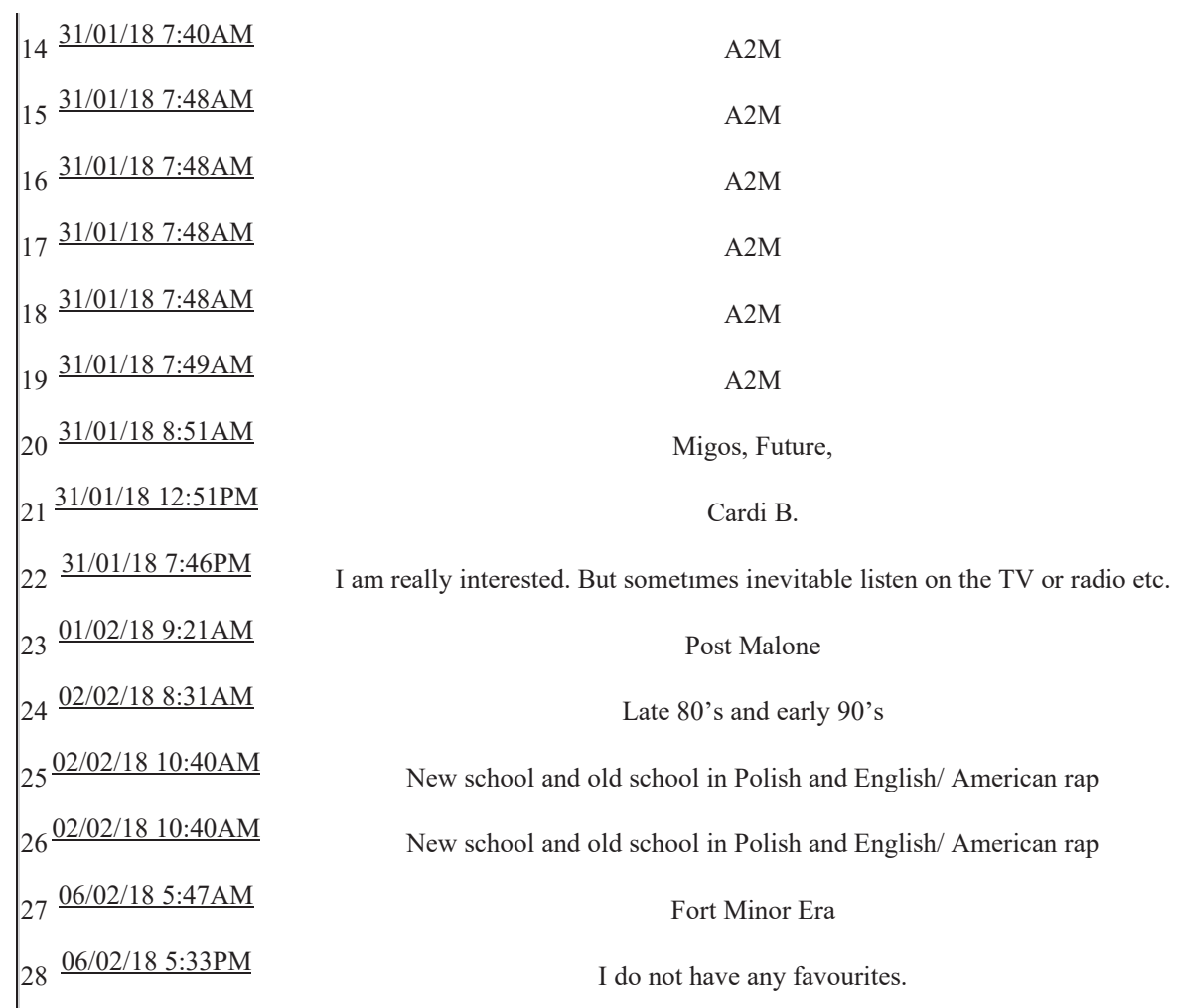

Source: Janiec, $2018 \mathrm{f}$

\section{Setup}

One may treat it as a controversial thesis, but the Hip-hop culture may work in favor of stimulating adolescents in the classroom. Besides a simplification-wise option, so by issuing grades or coming up with frames that are required to be assessed and giving positively-stimulus-like comments another likelihood, so a personalization of teaching at least used to be undervalued plus negatively exaggeratedly misunderstood. Moreover, the same style of life can be, after its successful implementation, a strategy to differentiate studies further integrate learners in the international community where we do have one main language of instruction.

One of the first topics to confer in a foreign group of teenagers, under a header "cultural differences", is language and meanings of one word in another spoken system of terms. Our learners are spending a tremendous time together laughing, deliberating and sometimes even arguing. And, so another time they are referring to their hobbies including listening to music expanding this speech on favorite genres as well as bands or crews. In essence, this is how the Hip-hop culture works likewise. 
In order to achieve motivation, differentiation and integration in the educational process we can use our knowledge, for instance on Australian representatives, for instance Sampa the Great, MANU CROOKS, Triple One; British: Dizzee, Stormzy, IAMDDB; Canadian: Drake, Moka Only, Classified; Chinese: Soft Lipa, MC Jin, J.Sheon; Czech: MAAT, Logic, ATMO; Estonian: Metsakutsu, 5LOOPS, PK; Finnish: Twwth, View, Ruger Hauer; French: NTM, MC Solaar, IAM; German: Nimo, Marteri, Haftbefehl; Indian: MC Prabh Deep, Mumbai's Finest, Dee MC; Greek: TXC, Zontani Nekri, Kings; Japanese: Anarchy, C.O.S.A., KANDYTOWN; Lithuanian: G\&G Sindikatas, Karu, Domas; New Zealander: Savage, Scribe, Che Fu; Norwegian: Arif, Kaveh, Conz; Portuguese: Sam the Kid, Boss AC, Dealema; Slovakian: H16, Vec, Kontrafakt; Slovenian: N'toko, Samo Boris, Tekochee Kru; Spanish: El Club de los Poetas Violentos, Mala Rodriguez, C Tangana; Turkish: Sagopa Kajmer, Ceza, Norm Ender and Polish: O.S.T.R., Eldo, Kaliber 44, and others.

\section{HHPED}

In the interdisciplinary unit entitled "Slavery", with a Key Concept: "Change" (definition in: Hirsh \& Triller 2014) and Global Context: "Orientation in Space and Time", students explore a question of colonization that led to slavery being seen differently by its eyewitnesses because of the offbeat time and space. What's the most telling; human beings will always find a way to express themselves artistically, even while facing a danger. And, so G9 learners examine and determine up-tothe-minute culture and its merchandise, namely the Hip-hop lyrics, as the three aforesaid strategies example, from the last 20 years, where their writers have been educating audience on the slavery, inequality, racism, social injustice literally as well as figuratively.

The teacher begins in-class discussion asking Socratic questions on standpoints and mindsets considering the Hip-hop culture in the $21^{\text {st }}$ century further on a poetic proof also rationale behind words on the matter. Then in the author's of this paper frame "Rhymes serve as the Primary Sources these days", aiming attention at the IB ATL transfer skill (IB, 2018), the learners are asked to read through given pieces of lyrics naming issues that are caused by the slavery, inequality as well as racism. In the second point they identify the author's feelings and emotions that might have stood behind each line detecting whether a reader is dealing with a historical innuendo to the times of colonization and slavery, personal experience or family's history. In the reference to the sources' origins and purposes students are ought to enlist their values and limitations. A selection of songs was made after Cara Shillenn's classes (2014) from the University of Maryland College Park: 
- Source A: Pusha T feat. The Dream "40 Acres" from album "My Name is My Name" (2013) ${ }^{17}$. Songwriters: Terius Nash and others. The Dream's call: "Trouble world, trouble child / Trouble times destroyed my smile / No change of heart, no change of mind / You can take what's yours but you gon' leave what's mine / I'd rather die, than go home / I'd rather die, than go home / And I ain't leaving without my 40 acres..." The Pusha T's response: "I need all mine, reparations / We growin' poppy seeds on my 40 acres."

- Source B: Nas "N.I. .*..E.R. (The Slave and the Master)" from the untitled album by Def Jam Recordings, $2008^{18}$ : "We are the slave and the master / what you lookin' for? You the question and the answer" (...) "we trust no black leaders / use the stove to heat us / powdered eggs and government cheeses (...) Schools with outdated books, we are the forgotten / Summers, coolin' off by the fire hydrant / Yeah, I'm from the ghetto."

- Source C: Black Star "Thieves in the Night" from the album "Mos Def \& Talib Kweli Are Black Star" (1998) ${ }^{19}$. Talib Kweli's words: "The wounds of slaves in cotton fields that never heal, what's the deal (...) / caught up, in conversations of our personal worth / brought up, through endangered species status on the planet Earth" (...) "that's why, we are subjected to the will of the oppressive / not free, we only licensed, not live, we just exciting / cause the captors own the masters to what we writing."

- Source D: Kendrick Lamar "Vanity Slaves" from the EP “The Kendrick Lamar" (2009) $)^{20}$ : "My cousin from the South said he just bought him a house / that lives around his neck like a white collar / so why fast forward? Then I'll rewind, a time / machine can help me double back to slavery times / picking cotton from a field that a white man own / the blacker you are, farther you're from the white man's home / (...) my cousin from the South, slavery start in the South and I bet ya / he overcompensates for the life of his ancestors."

\section{HHBE}

Additional model of the IB ATL transfer skill, in the HHBE prevailing taste using the aforesaid strategies, is to make generalizations while rephrasing a text from its author's personal approach, who was a slave. Further comparing and contrasting it

\footnotetext{
17 Check: https://open.spotify.com/track/2B6NMtdXWY2W76tZulV3v4.

18 Check: https://open.spotify.com/track/2k1EyoBJz7R65davb8zZ9W.

19 Check: https://open.spotify.com/track/7prM6PuZ5psmHNKhpznKbP.

${ }^{20}$ Check: https://open.spotify.com/track/72uNhnLDiUV8TAJWDuSMbX.
} 
with other writers' excerpts from a similar time frame. That's the reason why there is an urgency to introduce primary sources in a form of narratives from the $19^{\text {th }}$ century. This is also a suggestion for students to use mnemonic techniques in order to remember what was all the text about.

The G9 learners used John Jacob’s (1861) passage

to be a man, and not to be a man - a father without authority - a husband and no protector - is the darkest of fates. Such was the condition of my father, and such is the condition of every slave throughout the United States: he owns nothing, he can claim nothing. His wife is not his; his children are not his; they can be taken from him and sold at any minute, as far away from each other as the human flesh-monger may see fit to carry them. Slaves are recognized as property by the law and can own nothing except by the consent of their masters. A slave's wife or daughter may be insulted before his eyes with impunity. He himself may be called on to torture them, and dare not refuse. To raise his hand in their defense is death by the law. He must bear all things and resist nothing. If he leaves his master's premises at any time without a written permit, he is liable to be flogged.

Students adopted the aforesaid capacity in a very well manner by Dilpreet (G9):

John Jacobs/ to be a father/ a helpless husband rather/ having nothing at all/ from family to something small/ watching family get hurt/ and be nothing more than dirt/ this was the life of John Jacobs/ as we read from the text above;

To be a man / or not to be a man / a man who had no authority - a father / he was born by his mother / condition of a parent / they are nice I can't say that they aren't / they were calling us slaves / so, we are not going to make graves / now we are on the biggest wave / we had enough power to feel safe

Chorus: His wife is not his / his kids are not his / they are going to be taken / and sold for some kraken

By Konrad (G9):

Property of law is not his he can pray and he can squeeze / there is no way to leave his master/ even if he is going to kill him with a blaster/ he is able to be flogged/ but not even to be dogged"

The author of this paper decided to introduce, implement as well as use practically all of the already mentioned pillars of Hip-hop during History and Social Studies in the ISOB. Coming back to the transfer skills a teacher is changing a setup, so learners are able to exploit their prior knowledge. What's more, they are asked to evaluate the author's way of reasoning not forgetting on utilizing poetry while practicing making generalizations, shifting perspectives or judging. The learners' represents, rephrases and rewords a given matter in a form of lyrics, essay 
or graffiti made in the online Graffiti Creator. The Original. They are also taught self-assessment, plus self-adjustment while building their self-esteem.

Thanks to the "Accessibility" curriculum-based course they are making an interdisciplinary research on real-life questions that are based also on the issues adolescents are facing these days. For sure, a minority of these is enlisted in the concept-based classification through the Hip-hop/rap songs, see table 7.

Table 7. The author's concept-based classification of the Hip-hop/rap songs and issues students are facing these days. Meanings and interpretations after Shea Serrano (2015)

\begin{tabular}{|c|c|c|c|}
\hline \multicolumn{4}{|c|}{ “Accessibility” HHBE's \& HHPED's Example } \\
\hline Accessibility & Change [Novo] & Trust \& Honesty & Lies [Hoodoo] \\
\hline $\begin{array}{l}\text { Kendrick Lamar } \\
\text { [2017]: "DNA." }\end{array}$ & $\begin{array}{l}\text { Jay-Z (feat. Gloria Cart- } \\
\text { er) [2017]: "Smile" }\end{array}$ & $\begin{array}{l}\text { Obasi [2017]: } \\
\text { "Beast" }\end{array}$ & $\begin{array}{l}\text { Lil Uzi Vert [2017]: } \\
\text { "Xo Tour Llif3" }\end{array}$ \\
\hline $\begin{array}{l}\text { Kendrick Lamar } \\
\text { [2015]: } \\
\text { “i” }\end{array}$ & $\begin{array}{l}\text { Kendrick Lamar } \\
\text { [2017]: } \\
\text { "FEEL." }\end{array}$ & $\begin{array}{l}\text { Obasi [2017]: } \\
\text { "Pilgrims" (Editor's } \\
\text { Note) }\end{array}$ & $\begin{array}{l}\text { Obasi [2017]: } \\
\text { "Between the Lines" }\end{array}$ \\
\hline $\begin{array}{l}\text { Kendrick Lamar } \\
{[2011] \text { : }} \\
\text { " } F^{* * *} \text { Your Ethnicity" }\end{array}$ & $\begin{array}{l}\text { Obasi [2017]: } \\
\text { "Declaration of Inde- } \\
\text { pendece" }\end{array}$ & $\begin{array}{l}\text { Kendrick Lamar } \\
{[2011] \text { : }} \\
\text { "Ronald Reagan Era" }\end{array}$ & $\begin{array}{l}\text { Obasi [2017]: } \\
\text { "Glorify" }\end{array}$ \\
\hline $\begin{array}{l}\text { Jay-Z: “Takeover" vs } \\
\text { Nas: "Ether" [2001] }\end{array}$ & $\begin{array}{l}\text { Travis Scott [2017]: } \\
\text { "Butterfly Effect" }\end{array}$ & $\begin{array}{l}\text { Rick Ross [2006]: } \\
\text { "Hustlin"” }\end{array}$ & $\begin{array}{l}\text { Rap-O-Matic [2012]: } \\
\text { "Lies, Lies" }\end{array}$ \\
\hline $\begin{array}{l}\text { Nas [1994]: } \\
\text { "N.Y. State of Mind" }\end{array}$ & $\begin{array}{l}\text { Kanye West (feat.) } \\
\text { Jamie Fox [2005]: } \\
\text { "Gold Digger" }\end{array}$ & $\begin{array}{l}\text { Tupac [1996]: } \\
\text { "I ain't Mad at Cha" }\end{array}$ & $\begin{array}{l}\text { Eminem [2010]: } \\
\text { " } 25 \text { to Life" }\end{array}$ \\
\hline $\begin{array}{l}\text { Get Boys [1991]: } \\
\text { "Mind Playing Tricks } \\
\text { on Me" }\end{array}$ & $\begin{array}{l}\text { The Notorious B.I.G. } \\
\text { [1994]: "Juicy" }\end{array}$ & $\begin{array}{l}\text { Tupac [1995]: } \\
\text { "Dear Mama" }\end{array}$ & $\begin{array}{l}\text { Eminem (feat. Rihan- } \\
\text { na) [2010]: "Love the } \\
\text { way you lie" }\end{array}$ \\
\hline $\begin{array}{l}\text { Public Enemy [1990]: } \\
\text { "Fight the Power" }\end{array}$ & $\begin{array}{l}\text { Kurtis Blow [1980]: } \\
\text { "The Breaks" }\end{array}$ & $\begin{array}{l}\text { Whodini [1984]: } \\
\text { "Friends" }\end{array}$ & $\begin{array}{l}\text { Drake [2007]: } \\
\text { "Tell me Lies" }\end{array}$ \\
\hline
\end{tabular}

Source: the author

"Accessus" (Janiec, 2018a) from Latin an access because we all would like to belong to a given group, society, nation and country. Human beings are opening up to certain individuals and groups they can trust knowing that from the other side they can expect honesty as well as support. The aforementioned access is sometimes blocked as a result of historical, racial-ethnical, social, economic and cultural-religious-based differences. Knowing and understanding them is the key factor to proceed.

"Novo" (Janiec, 2018b) from Latin a change because we are all going on through better or worse alterations in our lives starting with growing up process that is not 
justifiable comfortably among youth. The most important thing is to answer to them in an adequate manner in order not to lose anything from our self-esteem.

"Mr. Trust \& Mrs. Honesty" (Janiec, 2018c) because we all need to have a person next to who and place, where we can be ourselves.

A word "Hoodoo" (Janiec, 2018d) derives from the West African traditional root working that was spread in America during the transatlantic slave trade between $16^{\text {th }}$ and $19^{\text {th }}$ century (Achebe, 1958; Hazzard-Donald, 2013; Harris, 2002; Hurston, 2008; Ogumefu, 200721). A person, who was a practitioner of this spiritually driven practices in secrecy, was called a "Worker", that's why the author used a nickname "MC Odd Worker". The practices were mainly undertaken to recover people's lives. The main insistence is put on the lies and a time to deal with them that should be treated as the healing process.

\section{Discussion}

The aforesaid methods and results of observations, interviews and in the last step survey establish a fact that plurality of juvenile plus adolescents between 12 and 20 years old is getting a handle on the Hip-hop culture in the international ISOB setting. Remembering about the homogeneous society and outsider effect. It is happening as an effect brought about by urgency to relate their feelings during maturing to lyrics written by their favourite rappers. What's more, some of the school's teachers and students' parents treat this art more as entertainment.

The emergence of the HHBE and HHPED differentiation strategies at the international school gave students a confidence in discussing historical venues launching in-depth analysis of such matters like a slavery, racism, discrimination, bullying, rejection, etc. Actually, learners felt that teachers heard them. To add, they can memorise dates and figures using mnemonic techniques learning English as their second language likewise.

Moreover, on the ground of the aforesaid methodologies a process of integration improved mostly thanks to small chitchats, debates, in class discussions on one's impressions in the given matter. It is also probable for growing ups to look for at least one more person, who thinks the same way as I do.

${ }^{21}$ A majority of African American literature has been already consulted with the expert in the field Mrs. Małgorzata Chrzan, PhD. (Assistant Professor at the Linguistics-Technical University in Świecie and English Literature in the Middle Years Program and Diploma Program teacher at the ISOB), in order to use it during History and Social Studies classes likewise. 
On the other hand, there is still a room to improve the survey by adding or changing suggested options to choose from. Definitely, a number of participants may affect the whole study. And, so the concept-based curriculum with activities plus the IB transfer skills may differ being dependent on the educational environment.

And lastly, the given investigation may work as the extension to the already mentioned studies (Irby \& Hall, 2013; Irby et al., 2013).

\section{Conclusion}

In essence, in some way a self-motivation among a younger generation at school would be achievable with guidance on personalization of teaching-learning process. Sometimes it is done automatically by the students, who are choosing this what interests them, the most. As the case of this article may be that the Hip-hop culture will be taken into account as another strategy to differentiate and integrate classmates with an extension to ambitiously teaching our learners the transfer skill in and within school classes.

\section{Bibliography}

Achebe Ch. (1958), Things Fall Apart, Everyman's Library, New York-London-Toronto.

Banks D. (2015), Hip hop as pedagogy: something from something, Theatre Topics vol. 25, no. 3, pp. 243-259.

Belka M.-Ch. (2013), Our real heroes, [in:] A. Viegas (ed.), Caro - Style Magazine. Personal Project Fashion Special by ISOB MYP Students, International School of Bydgoszcz, Bydgoszcz, pp. 14-15.

Boykins A. (2017), Hip-hop Takes the Throne, Passes Rock As Most Consumed Genre in U.S., https://hypebeast.com/2017/7/hip-hop-rock-most-consumed-music-genre-united-states, accessed: 11.02.2018.

Chang J. (2005), Can't Stop Won't Stop. A history of the Hip-hop generation, New York.

Coscarelli J. (2018), Kendrick Lamar wins Pulitzer in 'Big Moment for Hip-hop', https://www.nytimes. com/2018/04/16/arts/music/kendrick-lamar-pulitzer-prize-damn.html, accessed: 1.05.2018.

Emdin Ch. (2013a), Pursuing the pedagogical potential of the pillars of Hip-hop through science-mindedness, International Journal of Critical Pedagogy vol. 4. no. 3, pp. 83-99.

Emdin Ch. (2013b), The rap cypher, the battle, and reality pedagogy: developing communication and argumentation in urban science education, [in:] M.L. Hill, E. Petchauer (eds.), Schooling Hip-Hop. Expanding Hip-Hop Based Education Across the Curriculum, New York-London 2013, pp. 11-27.

Emdin Ch. (2017), On innervisions and becoming in urban education: Pentecostal hip-hop pedagogies in the key of life, Review of Education, Pedagogy, and Cultural Studies vol. 39, is. 1, pp. 106-119. DOI: 10.1080/10714413.2017.1262170. 
Emdin Ch., Adjapong E., Levy I. (2016), Hip-hop based interventions as pedagogy/therapy in STEM: A model from urban science education, Journal for Multicultural Education vol. 10, is. 3, pp. 307-321. DOI: 10.1108/JME-03-2016-0023.

Freire P. (2005), Pedagogy of the Oppressed, New York.

Hall H.B. (2016), 'Welcome to the shop': insights and reflections from teaching hip-hop-based spoken word poetry for social justice, English Teaching vol. 15, is. 3, pp. 394-410, DOI: https://doi. org/10.1108/ETPC-03-2016-0044.

Harkness G. (2012), True school: situation authenticity in Chicago's hip-hop underground, Cultural Sociology vol. 6, is. 3, pp. 283-298.

Harris J.Ch. (2002), The Complete Tales of Uncle Remus, New York.

Hazzard-Donald K. (2013), 'Mojo Workin'. The Old African American Hoodoo System, Urbana-Chicago-Springfield.

Hill M.L. (2006), Representin(g): Negotiating multiple roles and identities in the field and behind the desk, Qualitative Inquiry vol. 12, is. 5, pp. 926-949. DOI: 10.1177/1077800406288613.

Hill M.L. (2009a), Beats, Rhymes, and Classroom Life. Hip-Hop Pedagogy and the Politics of Identity, New York-London.

Hill M.L. (2009b), Wounded healing: forming a storytelling community in hip-hop lit, Teachers College Record vol. 111, no. 1, pp. 248-293. EJ826004.

Hirsch S., Triller Th. (2014), Individuals \& Societies. A Practical Guide. Teacher Book, Hague.

Hurtis Z.N. (2008), Tell my Horse: Voodoo and Life in Haiti and Jamaica, New York.

IB, Approaches to Learning Skills, Inquiry and Service Teacher Support Material, https://ibpublishing.ibo. org/server2/rest/app/tsm.xql?doc=m_0_mypxx_tsm_1412_1_e\&part=1\&chapter=1, accessed: 16.02.2018.

Irby D.J., Hall H.B. (2013), Fresh faces, new places: moving beyond teacher-researcher perspectives in hip-hop based education research, [in:] M.L. Hill, E. Petchauer (eds.), Schooling Hip-Hop. Expanding Hip-Hop Based Education Across the Curriculum, New York-London, pp. 95-117.

Irby D.J., Hall H.B., Mill M.L. (2013), Schooling teachers, schooling ourselves: Insights and reflections from teaching K-12 teachers how to use hip-hop to educate students, International Journal of Multicultural Education, vol. 15, is. 1.

Jacobs J.S. (1861), A true tale of slavery, The Leisure Hour: A Family Journal of Instruction and Recreation. Feb. 7, 14, 21, and 28, London.

Kline C. (2007). Represent!: Hip-hop and the Self-Aesthetic Relation. Bloomington, IN: https://scholarworks.iu.edu/dspace/bitstream/handle/2022/7659/umi-indiana-1617.pdf;sequence=1, accessed: 17.02.2017.

Kreps D. (2017), See the Roots' Black Thought Freestyle for 10 Minutes (Rolling Stone), https:// www.rollingstone.com/music/news/see-the-roots-black-thought-talk-epic-freestyle-on-fallon-w514180, accessed: 4.02.2018.

Kumar T. (2017), The battle for rap: problems and possibilities in teacher education, Teaching Education, pp. 1-10. DOI: 10.1080/10476210.2017.1377695.

Love B.L. (2012), Hip Hop's Li'l Sistas speak. Negotiating hip hop identities and politics in the New South, Studies in the Postmodern Theory of Education, vol. 399, New York.

Love B.L. (2014a), "I See Trayvon Martin”: What teachers can learn from the tragic death of a young black male, Urban Review, vol. 46, is. 2, pp. 292-306. DOI: https://doi.org/10.1007/s11256-013-0260-7.

Love B.L. (2014b), Urban storytelling: how storyboarding, moviemaking, and hip-hop-based education can promote students' critical voice, The English Journal, vol. 103, no. 5, pp. 53-58. DOI: 24484246. 
Love B.L. (2015), What is hip-hop based education doing in nice fields like early childhood and elementary education? Urban Education, vol. 50, is. 1, pp. 106-131. DOI: 10.1177/0042085914563182.

Love B.L. (2016), Complex personhood of hip hop \& the sensibilities of the culture that fosters knowledge of self \& self-determination, Equity and Excellence in Education vol. 49, is. 4, pp. 414-427, DOI: 10.1080/10665684.2016.1227223.

Lynch J. (2018), For The First Time in History, Hip-Hop Has Surpassed Rock To Become The Most Popular Music Genre, According to Nielsen, http://www.businessinsider.com/hip-hop-passes-rockmost-popular-music-genre-nielsen-2018-1?IR=T, accessed: 11.02.2018.

Noble J.M., Hedmann M.G., Williams O. (2016), Improving dementia health literacy using the FLOW Mnemonic: pilot findings from the Old SCHOOL Hip-Hop Program, Health Education and Behavior, vol. 42, is. 1, pp. 73-83. DOI: 10.1177/1090198114537063.

Nowacka P. (2013), 100\% dance, [in] A. Viegas (ed.), Caro - Style Magazine. Personal Project Fashion Special by ISOB MYP Students, Bydgoszcz, pp. 6-7.

Ogumefu M.I. (2007), “Yoruba Legends", Forgotten Books, www.forgottenbooks.org, accessed: 26.02.2018.

Petchauer E. (2009), Framing and reviewing Hip-hop educational research, Review of Educational Research, vol. 79. is. 2, pp. 946-978. DOI: 10.3102/0034654308330967.

Petchauer E. (2012), Hip-Hop Culture in College Students' Lives. Elements, Embodiment, and Higher Education, New York.

Petchauer E. (2013), I Feel What He Was Doin': urban teacher development, Hip-hop aesthetics, and justice-oriented teaching, [in:] M.L. Hill, E. Petchauer (eds.), Schooling Hip-Hop. Expanding Hip-Hop Based Education Across the Curriculum, New York-London, pp. 28-46.

Petchauer E. (2015), Starting with style: toward a second wave of Hip-hop education research and practice, Urban Education, vol. 50, is. 16, pp. 78-105. DOI: 10.1177/0042085914563181.

Pulido I. (2009), "Music fit for us minorities": Latinas/os' use of hip hop as pedagogy and interpretive framework to negotiate and challenge racism, \& Excellence in Education, vol. 42, is. 1, pp. 67-85. DOI: 10.1080/10665680802631253.

Ramirez-Sygutowska V. (2013), Hip-hop: inspiration and transformation, [in:] A. Viegas (ed.), Caro Style Magazine. Personal Project Fashion Special by ISOB MYP Students, Bydgoszcz, pp. 8-9.

Seidel S. (2011), Hip Hop Genius. Remixing high school education, Lanham-New York-TorontoPlymouth.

Serrano Sh. (2015), The Rap Year Book: The most important rap song from every year since 1979, discussed, debated, and deconstructed, Harry N. Abrams. E-book

Shillenn C. (2014), Rap, Hip Hop and Slavery, http://blog.umd.edu/musc204/author/cls51092/, accessed: 10.2.2018 (The class blog of MUSC 204, Spring 2014, University of Maryland College Park).

Shor I. (1992), Empowering Education: Critical teaching of social change, Chicago.

Smutny J.F., von Fremd S.E. (2004), Differentiating for the Young Child: Teaching strategies across the content areas (K-3), London.

Söderman J. (2011), Folkbildning through Hip-hop: How the ideals of three rappers parallel a scandinavian educational tradition, Music Education Research vol. 13, is. 2, pp. 211-225. DOI: 10.1080/14613808.2011.577929.

Stovall D. (2013), Hip-hop and the new response to urban renewal: youth, social studies, and the bridge to college, [in:] M.L. Hill, E. Petchauer (eds.), Schooling Hip-Hop: Expanding Hip-hop based education across the curriculum, New York-London, pp. 155-166. 
Tinson Ch.M., McBride C. (2013), Hip hop, critical pedagogy, and radical education in time of crisis. radical teacher, A Socialist, Feminist, and Anti-Racist Journal on the Theory and Practice of Teaching, no. 97, https://radicalteacher.library.pitt.edu/ojs/index.php/radicalteacher/article/ viewFile/43/30, accessed: 8.02.2018.

Williams O., DeSorbo A., Noble J., Gerin W. (2012a), Child-mediated stroke communication: Findings from Hip Hop stroke. Stroke vol. 43, is. 1, pp. 163-169. DOI: 10.1161/STROKEAHA.111.621029.

Williams O., DeSorbo A., Noble J., Shaffer M., Gerin W. (2012b), Long-term learning of stroke knowledge among children in a high-risk community, Neurology vol. 79, is. 8, pp. 802-806.

Williams O., DeSorbo A., Sawyer V., Apakama D., Shaffer M., Gerin W., Noble J. (2016), Hip Hop HEALS: Pilot study of a culturally targeted calorie label intervention to improve food purchases of children, Health Education and Behavior vol. 43, is. 1, pp. 68-75. DOI: https://doi. org/10.1212/WNL.0b013e3182661f08.

Williams O., Noble J.M. (2008), 'Hip-Hop' stroke: A stroke educational program for elementary school children living in a high-risk community, Stroke vol. 39, is. 10, pp. 2808-2816. DOI: 10.1161/STROKEAHA.107.513143.

Wilson J.A. (2013), The MC in Y-O-U: leadership pedagogy and southern hip-hop in the HBCU Classroom, [in:] M.L. Hill, E. Petchauer (eds.), Schooling Hip-Hop. Expanding Hip-hop based education across the curriculum, New York-London, pp. 66-92.

Wood K. (2013), Who's melting in the suburban Pot? Diversity in the Chicago suburbs, [in:] E. Banka, M. Liwinski, K. Rusilowicz, America Scapes. Americans in/and their diverse sceneries. Studies in Literature and Culture, vol. 9, Lublin, pp. 255-276.

Zatat N. (2017), Harvard Student graduates with Honours after submitting Rap Album as final Year Thesis, http://www.independent.co.uk/arts-entertainment/harvard-student-rap-album-final-year-thesis-passes-second-highest-grade-ivy-league-obasi-shaw-a7747371. html, accessed: 28.01.2018.

\section{Dance studios in Bydgoszcz}

Adelante. Studio tańca, http://www.u2e.pl, accessed: 5.02.2018.

Bailamos Dance Studio: Robert Linowski, Carolina Linowska, http://bailamos.pl, accessed: February $5,2018$.

Fabryka Tańca - Studio Tańca, http://www.fabrykatanca.com, accessed: 5.02.2018.

Studio Kreacji Tańca. Nauka tańca. Neumann B.M., http://studiokreacjitanca.pl, accessed: 5.02.2018.

Studio Tańca Dance Academy Agata Szybiak-Loukini, Radosław Gołata, http://taniec-bydgoszcz.pl, accessed: 5.02.2018.

Szkoła Tańca "Bohema”, http://www.szkolabohema.pl, accessed: 5.02.2018.

Up2Excellence Studio Tańca Bydgoszcz, http://www.u2e.pl, accessed: 5.02.2018.

\section{Documentary}

Wheeler D. (2016), Hip Hop Evolution, Banger Films.

\section{Graffiti creator (online)}

Graffiti Creator. The Original, http://www.graffiticreator.net, accessed: 5.02.2018. 


\section{Hip-hop songs}

Black Star, Thieves in the Night, https://open.spotify.com/track/7prM6PuZ5psmHNKhpznKbP, accessed: 5.02.2018.

Janiec J. (2018a, under a nickname: MC Odd Worker), Accessus, https://youtu.be/A7yoaxaXYmQ, accessed: 1.03.2018.

Janiec J. (2018b, under a nickname: MC Odd Worker), Hoodoo, https://youtu.be/imHszCGgJu8 , accessed: 1.03.2018.

Janiec J. (2018c, under a nickname: MC Odd Worker), Mr. Trust \& Mrs. Honesty, https://youtu.be/ U4qDnLi_Dio, accessed: 1.03.2018.

Janiec J. (2018d, under a nickname: MC Odd Worker), Novo, https://youtu.be/YncduS3dCdA, accessed: 1.03.2018.

Janiec J. (2018e, under a nickname: MC Odd Worker), Stylo Theory, https://youtu.be/DQygkIVvyz4, accessed: 5.03.2018.

Lemar K., The Vanity Slave, https://open.spotify.com/track/72uNhnLDiUV8TAJWDuSMbX, accessed: 8.02.2018.

Nas, $\mathrm{Ni}^{* *}$ er (The Slave and the Master), https://open.spotify.com/track/2k1EyoBJz7R65davb8zZ9W, accessed: 8.02.2018.

Obasi, Liminal Minds, https://www.youtube.com/watch?v=pMjrQ8_vPHw, published on: May 28, 2017; accessed: 28.01.2018.

Pusha T, The Dream, 40 Arces, https://open.spotify.com/track/2B6NMtdXWY2W76tZulV3v4, accessed: 8.02.2018.

\section{Library}

Harvard Library, Catalogue, http://library.harvard.edu, accessed: 18.02.2018.

\section{Survey}

Janiec J. (2018f), Hip-Hop: Pick up the majority's Speech, http://www.smartsurvey.co.uk/s/0E2QT/, accessed: 1.02.2018. 